\title{
ESTUDOS DO PROCESSO DE QUEIMA DA CERÂMICA PRÉ-HISTORICA DO SÍTIO ARQUEOLÓGICO SERRA DO EVARISTO I ${ }^{1}$ - BATURITÉ-CE/BRASIL.
}

\author{
Claudia Oliveira ${ }^{1}$, Lucila E. P. Borges ${ }^{2}$, Igor Pedroza ${ }^{3}$, Emília A. Arnaldo, ${ }^{3}$,Viviane Castro ${ }^{1}$, Neuvânia \\ C. Ghetti ${ }^{1}$
}

${ }^{1}$ Universidade Federal de Pernambuco - UFPE, Departamento de Arqueologia. ${ }^{2}$ Departamento de Geologia. ${ }^{3}$ Programa de Pós-Graduação em Arqueologia, Recife, PE. E-mail: ester@ufpe.br

\section{RESUMO}

Essa pesquisa analisa o processo de queima da cerâmica pré-histórica do sítio arqueológico Serra do Evaristo I, localizado no município de Baturité, no estado do Ceará, na região Nordeste do Brasil. Na análise deste material verificou-se uma variação na coloração da cerâmica que pode indicar diferentes processos de queima. Entretanto, no contexto pré-histórico e etno-histórico dos grupos no Nordeste do Brasil, as informações apontam para utilização apenas da queima em atmosfera oxidante. Desta forma questiona-se se essa variação estaria relacionada a diferentes processos de produção da cerâmica ou a diferentes tipos de argila. Para este objetivo foram realizadas análises petrográficas e aplicada a técnica de Difratometria por Raios-X (RXD). Verificase que as ceramistas da Serra do Evaristo I utilizavam argilas de dois depósitos distintos e que poderiam misturar os dois tipos de argilominerais de acordo com o tipo de vasilha a ser produzida. Palavras-chave: mineralogia das argilas, cerâmica pré-histórica, queima, grupos agricultores ceramistas, Nordeste de Brasil.

\section{STUDIES OF FIRING PROCESS OF PREHISTORIC CERAMIC IN ARCHAEOLOGICAL SITE SERRA DO EVARISTO I - BATURITÉ-CE/BRASIL.}

\begin{abstract}
This investigation evaluated the burn process in prehistoric ceramic from the Serra do Evaristo I, an archaeological site, located in Baturité, Ceará, in Northeast Brazil. The material analysis shows variation in the material coloration that can indicate different burning processes. However, in a prehistoric and ethno-historic context of the groups from the Brazilian northeast, the usual data shows only the burning process in an oxidant atmosphere. Therefore, there remains a question concerning whether this variation is related to different production processes of the ceramic material or to the different types of the clays. With the objective of clarifying this question, X-Ray Diffractometry (RXD) petrographic analysis were performed on the material. It was verified and shown that the Serra do Evaristo I ceramists used two types of clays originating from two different places and that they could mix the two clay minerals according to the type of vessels that were produced.
\end{abstract}

Keywords: clay mineralogy, prehistoric ceramic, burns, agricultural ceramists groups, Brazilian northeast.

\footnotetext{
${ }^{1}$ Esse sítio foi registrado no Cadastro Nacional de Sítios Arqueológicos (CNSA/SGPA) sob o código CE00455, no ano de 2010, com o nome Cemitério Indígena Serra do Evaristo, em virtude dos primeiros achados casuais. Por conta da pesquisa realizada, passamos a adotar o nome de "Serra do Evaristo", uma vez que a denominação de cemitério indígena já não contempla o contexto arqueológico do sítio.
} 


\section{INTRODUÇÃO}

A identificação do processo de queima dos objetos cerâmicos é, provavelmente, o aspecto que gera mais problemas numa análise feita pela simples observação dos vestígios. Aparentemente se poderia reconhecer imediatamente o tipo de queima à qual foram submetidas às peças, porém os elementos identificadores se constituem de um alto grau de ambiguidade. O principal problema observado se refere aos elementos indicadores dos tipos de queima, que não são suficientemente seguros, pois um mesmo indicador pode ter sido originado por procedimentos diferentes.

Na queima da cerâmica identificam-se processos de dois tipos: aberto, no qual as peças são submetidas à cocção ao ar livre, ou em fornos de vários tipos, onde se pode obter uma atmosfera oxidante ou redutora. $\mathrm{Na}$ inexistência de um forno fechado, os grupos pré-históricos poderiam aproveitar uma depressão no chão (RYE, 1981; SHEPARD, 1961; WILEY, 1986). Contudo, nos explica Canotilho (2003) que no:

[...] caso dos fornos que
utilizam combustíveis
minerais e lenhosos,
liberta-se o carbono [C],
obtendo-ser portanto
umarasfera
Redutora. Neste tipo de
forno, não existe
qualquer limitação
quanto à entrada de
oxigênio, pelo que é
possível conseguir

também uma atmosfera Oxidante (CANOTILHO, 2003, p. 42).

Nos últimos anos, a troca de conhecimentos entre arqueólogos, historiadores, físicos, geólogos e químicos, em relação ao estudo de materiais arqueológicos, demonstra o quanto a interdisciplinaridade tornou-se importante para a classificação dos artefatos cerâmicos. Dessa forma muitos trabalhos têm sido realizados e resultam numa série de informações que se complementam para caracterizar uma importante área da pesquisa.

\section{LOCALIZAÇÃO E MEIO AMBIENTE}

O município de Baturité está integrado a um dos mais importantes enclaves de mata úmida do Ceará, a Serra de Baturité, que é caracterizada como um ambiente de exceção do bioma da Caatinga (SOUZA, 2011). Está situado na porção norte do Estado do Ceará, nordeste brasileiro (Figura 1) e limita-se ao norte com os municípios de Redenção, Pacoti e Guaramiranga; ao sul, com Capistrano, Itapiúna e Ibaretama; ao leste, com Aracoiaba e Redenção e, por fim, com Guaramiranga, Mulungu e Capistrano a oeste. Sua divisão administrativa é composta pelo distrito sede (Baturité) e os de Boa Vista e São Sebastião. Possui área absoluta de 308 
$\mathrm{km}^{2}$ e está distante da capital do estado,

Fortaleza, a aproximadamente $90 \mathrm{~km}$ (IPECE,
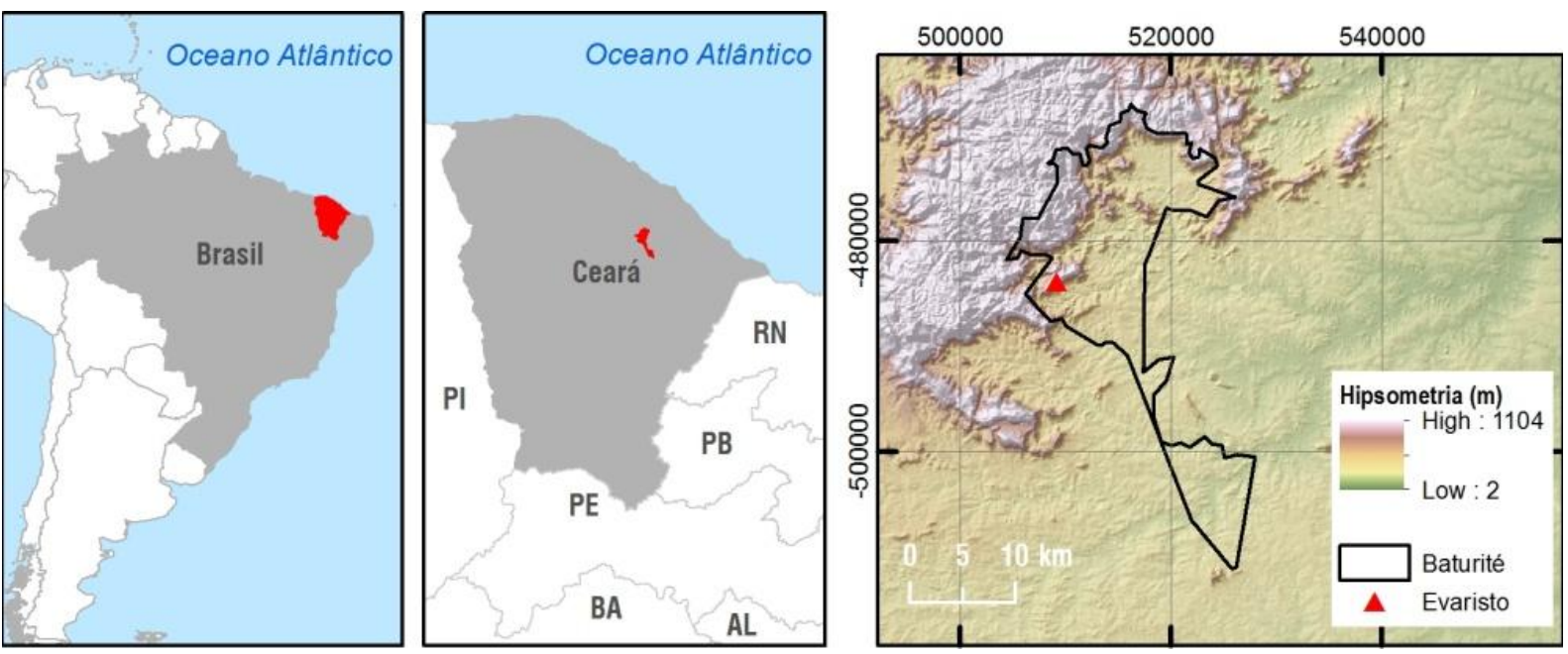

Figura 1. Localização do município de Baturité e do sítio Serra do Evaristo I Fonte: Pedroza (2015)

A região é caracterizada geomorfologicamente como Maciço do Baturité. Seu relevo é formado por elevações entre 600 e $1200 \mathrm{~m}$ e depressões resultantes das variações paleoclimáticas e de processos morfodinâmicos (CAVALCANTE, 2005; IBAMA, 2002). Possui solo Podzólico vermelho (PVd1) de matriz argilosa e alto teor de umidade e fertilidade (CEARÁ, 1992). Os tributários abastecem duas grandes bacias hidrográficas cearenses: a) a Bacia do Curu, na vertente ocidental do Maciço e b) a Bacia Metropolitana, na porção oriental, na Subbacia do Rio Choró. Destaca-se como um dos principais afluentes o Rio Aracoiaba, localizado no município de Baturité (NUNES; PORTELA, 2011).

O clima na microrregião de Baturité apresenta duas classificações distintas: a)

2014). 
Rangel Filho e Lima (1991), a Floresta Atlântica Nordestina está subdivida em Floresta Estacional Semidecidual Montana e Floresta Ombrófila Densa Montana, em associação a elementos da Caatinga arbustiva (vegetação xerofítica). As formações vegetais registradas são: a) Mata Úmida; b) Mata Seca; c) Caatinga; e d) Mata ciliar (CAVALCANTE, 2005). A presença de espécies da Mata Atlântica, como o limãozinho (Zanthoxylum rhofolium), o amarelão (Buchenavia capitata), o murici (Byrsonima sericea), o ipê-amarelo (Tabebuia serratifolia), imbiriba (Xylopia morototoni), frei-jorge (Cordia trichotoma) e gargaúba (Schefflera morotoni) e da Floresta Amazônica, como a favinha (Stryphnodendron purpureum), a paraíba (Simarouba amara) e a copaíba (Copaifera langsdorfii) ocorrentes na Serra de Baturité sustentam a hipótese de conexão florística com florestas úmidas no passado (Santos et al., 2008). A região possui a maior riqueza e diversidade de espécies da flora e da fauna registradas no Estado do Ceará, sendo a área considerada um refúgio ecológico (MANTOVANI, 2007). Desde 2000, a região tornou-se uma Área de Proteção Ambiental (APA Serra de Baturité) (OLIVEIRA; ARAUJO, 2007).

\section{O SÍTIO SERRA DO EVARISTO I}

O sítio arqueológico Serra do Evaristo I está situado na serra homônima, uma localidade distante $9 \mathrm{~km}$ da sede municipal de Baturité, sob as coordenadas SIRGAS UTM 24 M E509189/N9516152 e elevação de 533m (NMM). A partir da sede do município, o acesso é realizado por uma estrada estreita, sinuosa e de aclive acentuado, dotando ainda hoje a área de características de difícil acesso e isolamento (

Figura 2). 


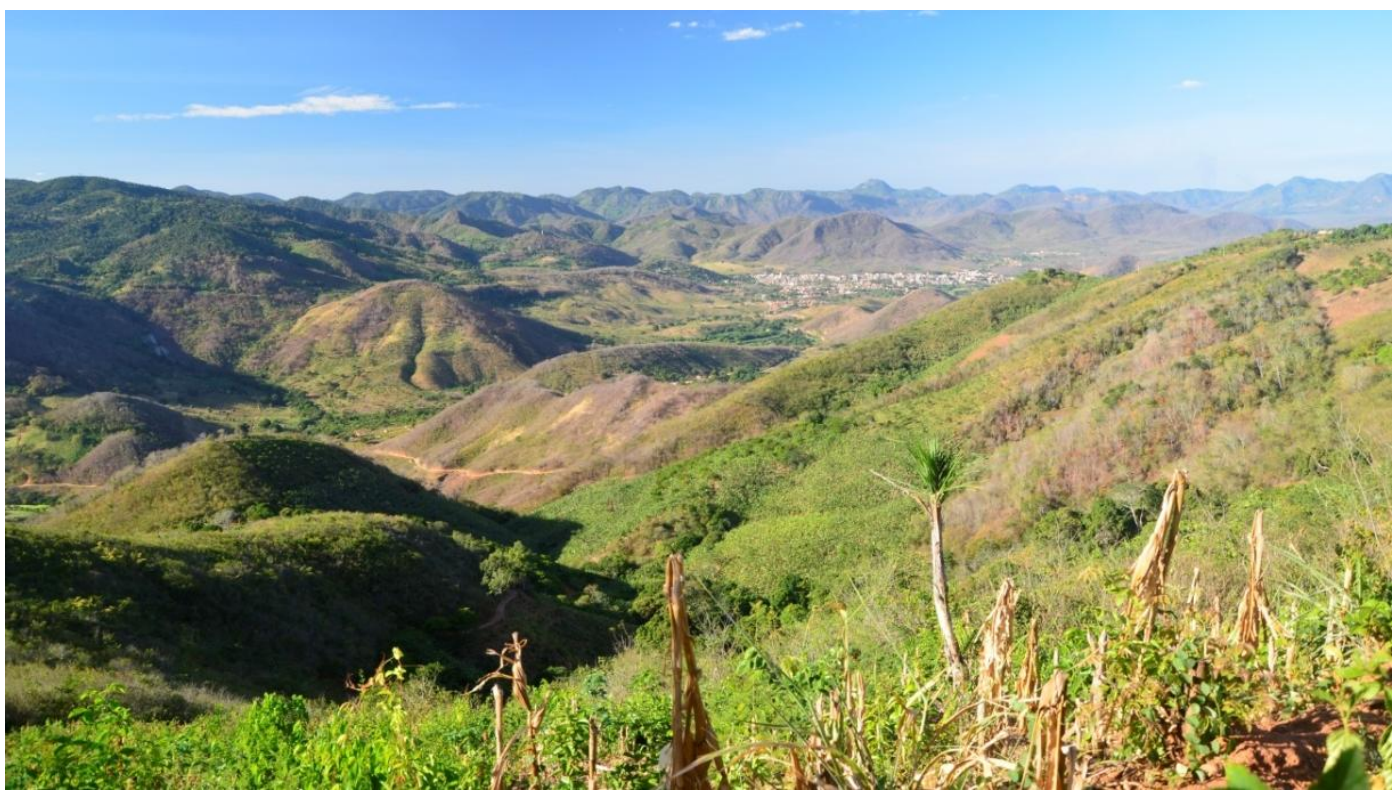

Figura 2. Vista do município de Baturité a partir da Serra do Evaristo

Fonte: Pedroza (2015)

A pesquisa arqueológica no sítio Serra do Evaristo $\mathrm{I}^{2}$ ocorreu como resposta às reivindicações da comunidade para garantir a salvaguarda do patrimônio arqueológico, uma vez que diversos vestígios afloravam nos quintais e ruas da comunidade, inclusive três vasilhas cerâmicas já haviam sido retiradas do solo pela comunidade, tendo remanescentes ósseos em uma delas.

\section{AS ATIVIDADES DE CAMPO}

As atividades de campo no sítio Serra do Evaristo I foram iniciadas com 0 levantamento planialtimétrico com uso de estação total, após a implantação dos marcos topográficos, devidamente georreferenciados

\footnotetext{
2 A pesquisa foi financiada pela Superintendência estadual do Instituto do Patrimônio Histórico e Artístico Nacional no Ceará (IPHAN-CE), sendo executada ao longo do ano de 2012 por pesquisadores e alunos da Universidade Federal de Pernambuco (UFPE), da Universidade Estadual do Ceara (UECE), da Universidade Federal do Ceará (UFC), e jovens da comunidade da Serra do Evaristo.
}

com uso de GPS Geodésico. Em seguida foram identificadas as áreas onde as vasilhas já estavam expostas, designadas como unidades de escavação (UE's). Com isso, 18 unidades (UE's 01, 02, 03, 04, 05, 06, 07, 08, $09,10,11,12,13,14,15,16,17,18$ e 19) com dimensões diversas e uma trincheira de $2 \times 4 m$ foram escavadas, em geral, por camadas artificiais de $10 \mathrm{~cm}$, visando o resgate das vasilhas e a obtenção de dados gerais sobre sua deposição (Figura 3).

As unidades de escavação, onde foram identificadas as vasilhas cerâmicas, foram escavadas $\mathrm{e}$ as mesmas foram envolvidas em filme PVC e retiradas do solo (Figura 4). No total foram resgatadas 18 vasilhas, contudo, não foram identificadas quaisquer marcas de cova. A escavação do interior das vasilhas foi realizada em laboratório, para evitar fragmentação e a 
perda de seus conteúdos. Além das escavações e coletas nas unidades de escavação foi realizada ampla prospecção de superfície e suas devidas coletas (Figura 5). Em termos quantitativos, o vestígio arqueológico predominante foi a cerâmica, em $90 \%$ da coleção.

Ao final do trabalho de campo foram identificados os seguintes vestígios:

- fragmentos cerâmicos (bojo, borda, base, bojo-base);

- fusos inteiros e fragmentados, um deles com 12 cm de diâmetro;

- fragmento de cachimbo;
- artefatos lascados (núcleos, lascas e instrumentos);

- conta de colar em quartzo;

- Fragmentos de micro fauna e malacológicos;

- lâminas polidas, picoteadas e lascadas;

- vasilhas globulares, ovóides e piriformes de grande dimensão;

- Olaria.

Além dos vestígios arqueológicos citados acima foram coletadas as seguintes amostras: sedimento para análises polínicas, datação (LOE), e micromorfologia dos solos (caixa Kubiena); e carvão para datação;

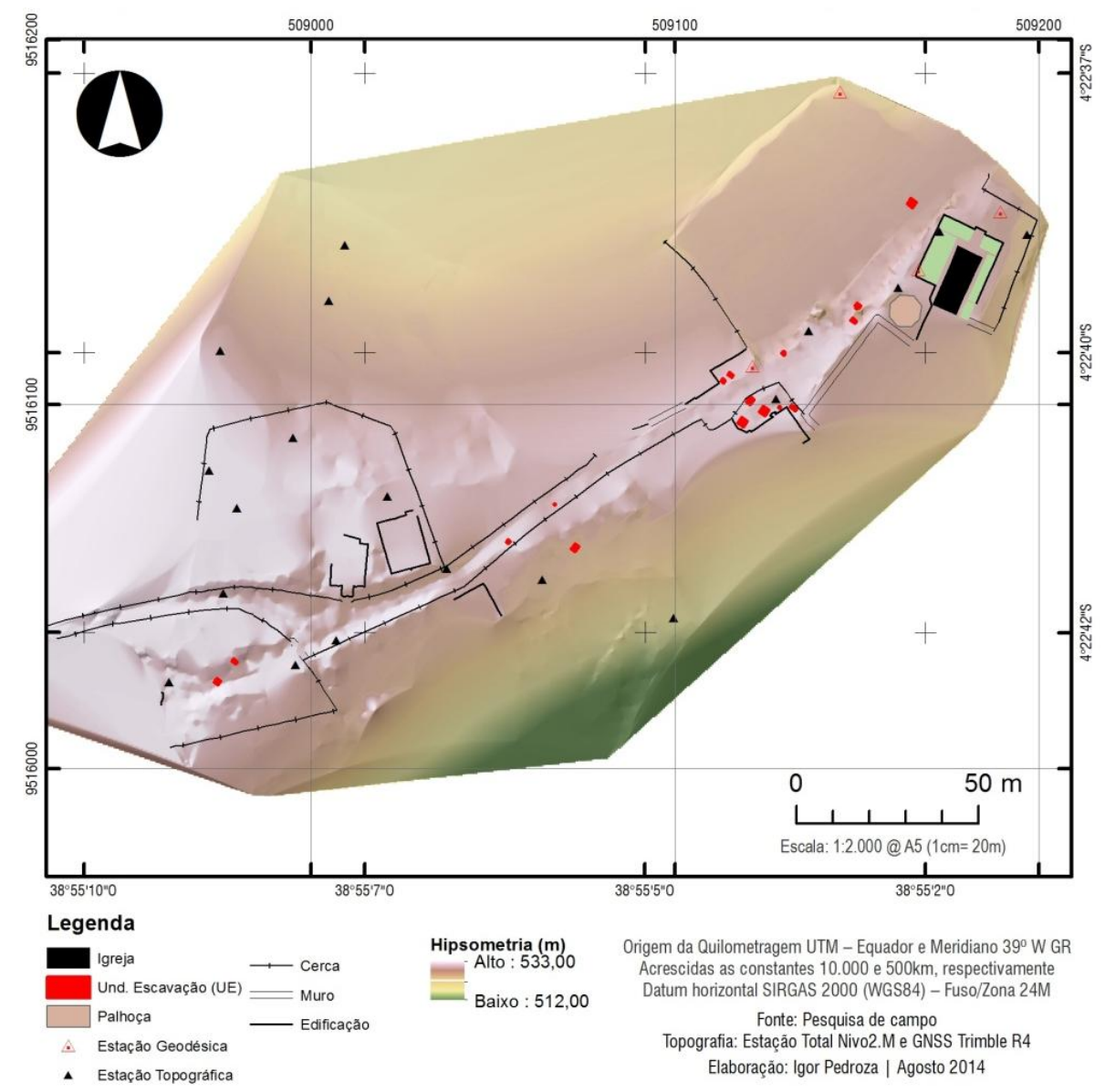

Figura 3. Modelo Digital do Terreno (MDT) e localização das unidades de escavação (polígono vermelho) do sítio arqueológico Serra do Evaristo I 
Fonte: Elaboração de Igor Pedroza, 2014

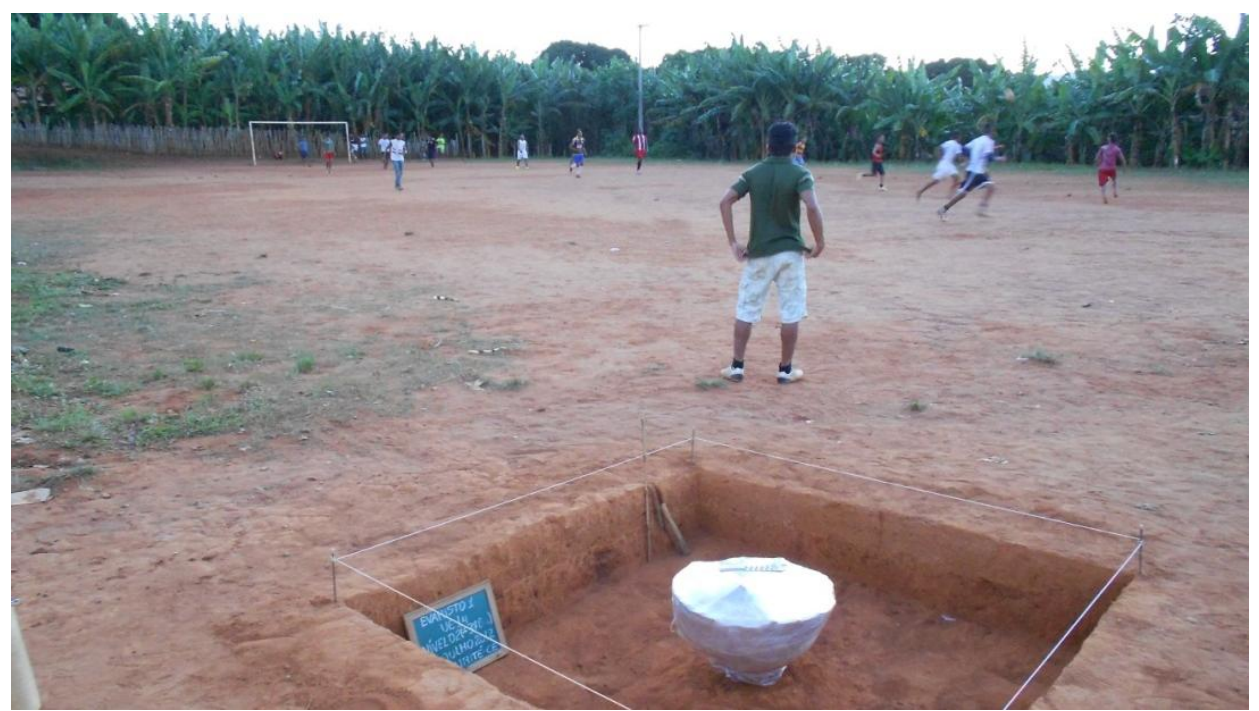

Figura 4. Fase final da escavação na UE14 com a vasilha envolta em filme PVC Fonte: Pedroza (2015)

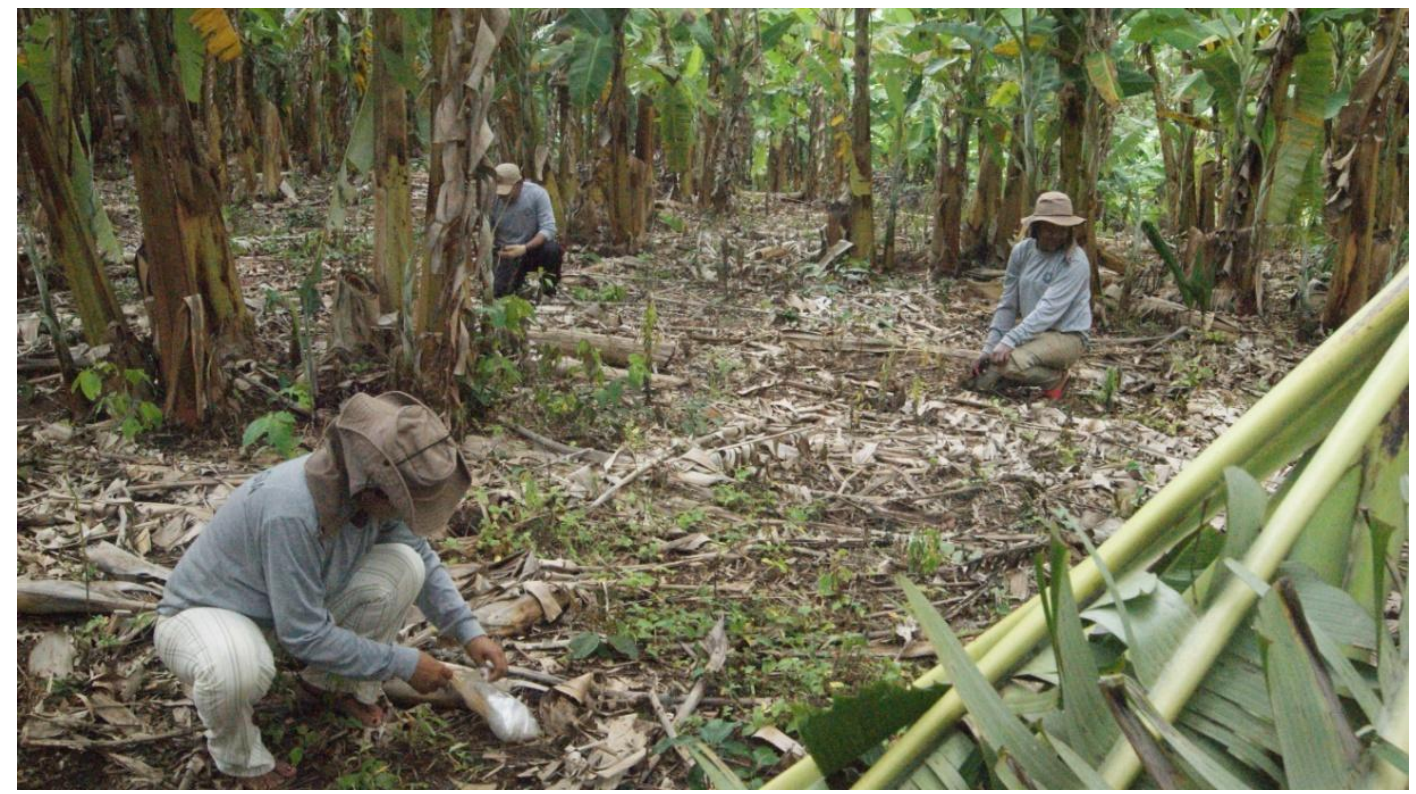

Figura 5. $\mathrm{Na}$ área de bananeiras, cultura predominante no local, ensacamento de vestígios para coleta sistemática de superfície com uso de estação total Fonte: Pedroza (2015)

Os ceramistas que ocuparam a região da Serra do Evaristo apresentavam artefatos cerâmicos diversificados. As vasilhas alcançavam dimensões extremas, variando entre $15 \mathrm{~cm}$ a $70 \mathrm{~cm}$ de diâmetro e de $15 \mathrm{~cm}$ a $80 \mathrm{~cm}$ de altura, com espessuras das paredes inferiores a $0,5 \mathrm{~cm}$ e superiores a $3,5 \mathrm{~cm}$. Os recipientes maiores apresentavam forma ovóide, tendendo a piriforme e os menores, forma globular. Esses grupos ceramistas produziam também cachimbos (Figura 6) e fusos (Figura 7). 


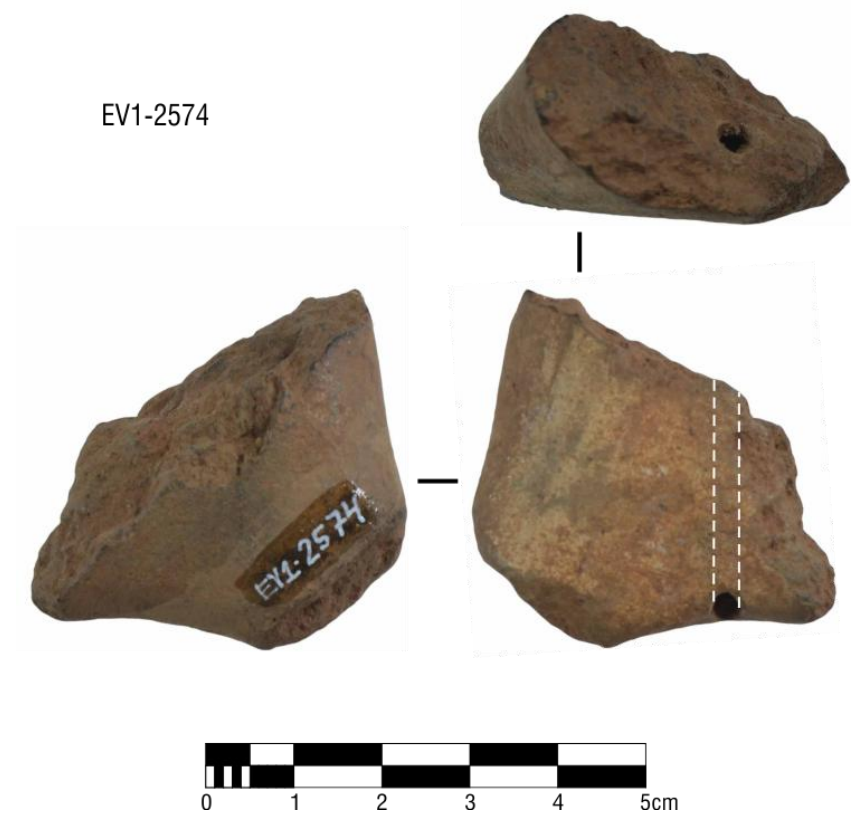

Figura 6. Fragmento de cachimbo

Fonte: Igor Pedroza (2015)

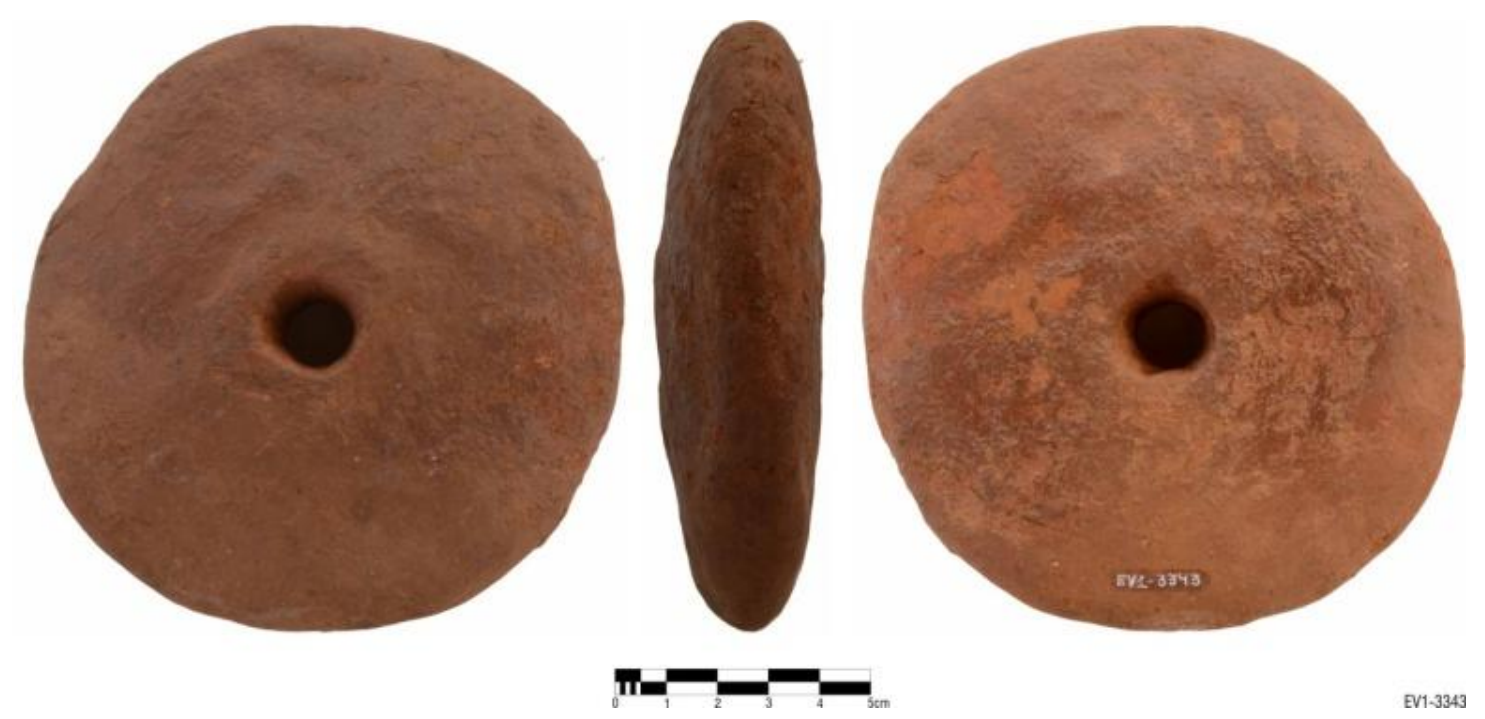

Figura 7. Rodela de fuso com $12 \mathrm{~cm}$

Fonte: Pedroza (2015)

Entre as dezoito (18) vasilhas ósseos humanos (vasilhas V2C, V3, V5, V7A, cerâmicas escavadas no sítio, apenas seis V8 e V14) (Figura 8).

(33,33\%) apresentaram remanescentes 


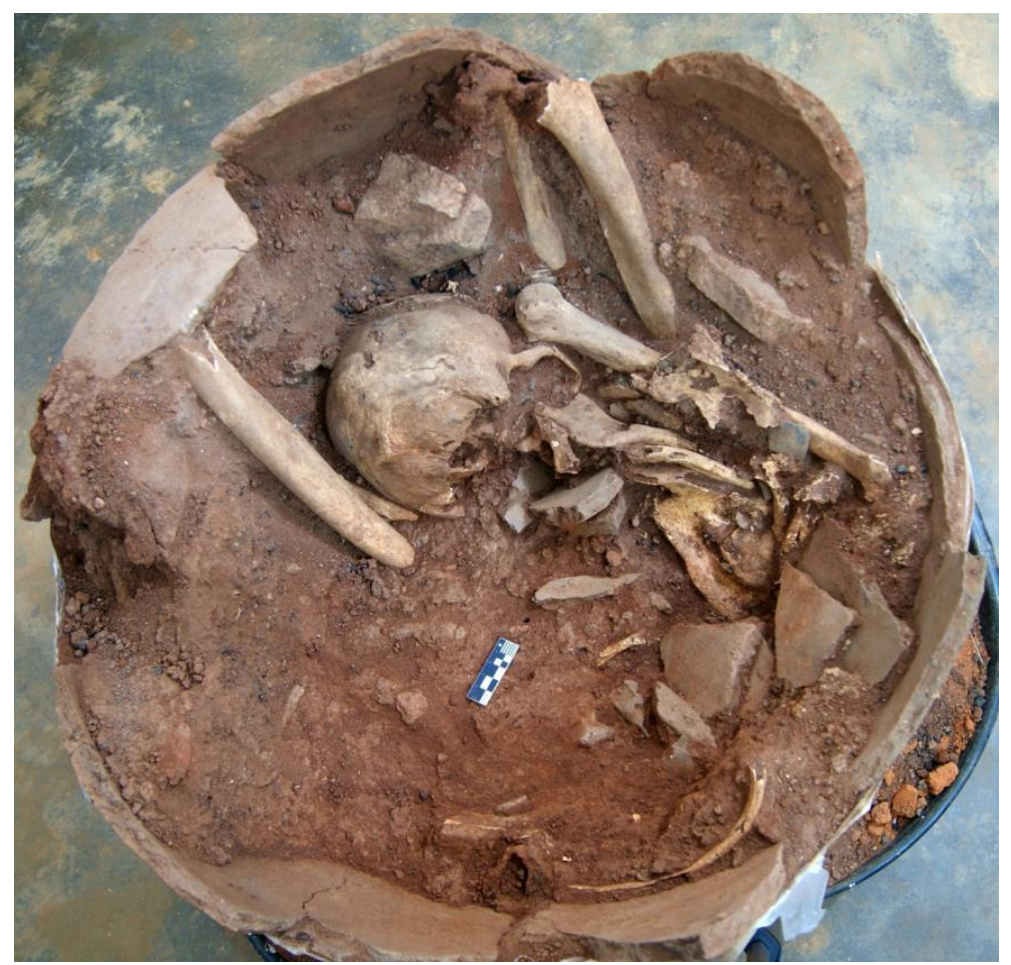

Figura 8. Sepultamento primário de indivíduo adulto e masculino - V2C

Fonte: Pedroza (2015)

O material lítico analisado está representado por lâminas de machados de forma retangular e trapezoidal, com curvaturas longitudinais e transversais do gume arredondado ou plano, com lados arredondados, ou planos. A matéria-prima predominante é o granito. Apresentam as técnicas do picoteado, do polido e do lascado (Figura 9). Também foram identificados dois fragmentos de mão de pilão em quartzo.

Havia também núcleos, lascas, fragmentos, instrumentos não modificados com marcas de uso, como percutores, alisadores/ polidores em quartzo, quartzito em forma de seixos, micaxisto e granito em forma de fragmento natural. Foram identificados elementos com presença de algum tipo de desgaste nas extremidades, e nas faces dos seixos pouco alongados, tais desgastes podem ser produtos da percussão ou da fricção com outra superfície rochosa.

Além dos artefatos líticos descritos acima foram encontrados durante as escavações duas peças de adornos: um fragmentado em quartzo e que se assemelha a um fuso, porém mais alongado, e apresenta forma elipsoide com um furo em seu interior e com polimento em toda a área externa; outro, provavelmente uma conta de colar polida, também confeccionado em quartzo. 


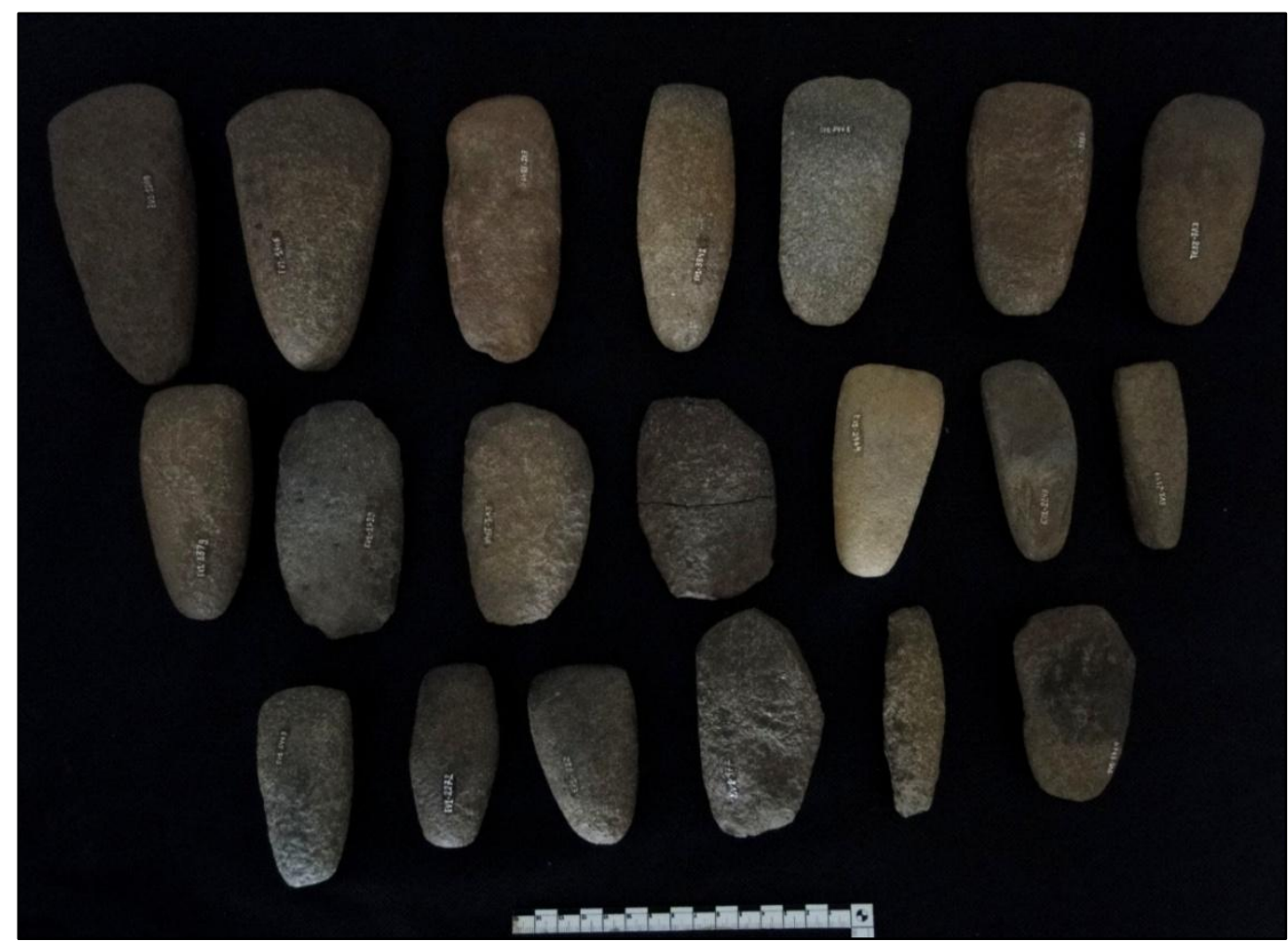

Figura 9. Lâminas polidas e picoteadas

Fonte: Arnaldo (2015)

da técnica Accelerator Mass Spectrometry

A partir de carvão aderido ao osso (AMS), uma vez que possibilita maior temporal esquerdo do esqueleto da UE02 precisão da idade obtida, mesmo com (V2C) e carvão que se encontrava na base amostras diminutas (Tabela 1).

interna da vasilha da UE11 foram realizadas duas datações por carbono $14\left(\mathrm{C}^{14}\right)$, com uso

Tabela 1. Datações radiocarbônicas realizadas no sítio Serra do Evaristo I em 2012

\begin{tabular}{|c|c|c|c|c|}
\hline $\begin{array}{c}\text { Amostra } \\
\text { Laboratório }\end{array}$ & $\begin{array}{c}\text { Idade } \\
\text { radiocarbônica }\end{array}$ & $\begin{array}{c}\text { Idade } \\
\text { calibrada } \\
(2 \sigma)\end{array}$ & $\begin{array}{l}\text { Material } \\
\text { Datado }\end{array}$ & Contexto \\
\hline $\begin{array}{l}\text { Laboratório } \\
\text { Beta Analityc. } \\
\text { Amostra } \\
328350 / \\
2012\end{array}$ & $670 \pm 30 \mathrm{BP}$ & $\begin{array}{c}1280-1320 \text { e } \\
1350-1390 \\
\text { DC }\end{array}$ & Carvão & $\begin{array}{c}\text { Aderido ao osso } \\
\text { temporal } \\
\text { esquerdo do } \\
\text { esqueleto da } \\
\text { UE02 (V2C) }\end{array}$ \\
\hline $\begin{array}{l}\text { Laboratório } \\
\text { Beta Analityc. } \\
\text { Amostra } \\
328351 / \\
2012\end{array}$ & $660 \pm 30 \mathrm{BP}$ & $\begin{array}{c}1280-1320 \text { e } \\
1350-1390 \\
\text { DC }\end{array}$ & Carvão & $\begin{array}{l}\text { Base interna da } \\
\text { vasilha da UE11 }\end{array}$ \\
\hline
\end{tabular}




\section{PROCESSOS DE QUEIMA DA CERÂMICA}

Para estudar a produção tecnológica de uma cerâmica é necessário conhecer as técnicas de manufatura, técnicas decorativas, pastas, tratamento de superfície e temperatura de queima. De acordo com Nunes (2009), após ser moldada pelo ceramista, é necessário que a pasta cerâmica passe por um processo de secagem, para que finalmente seja submetida a uma alta temperatura. Esta temperatura elevada é capaz de atribuir rigidez à pasta, transformando-a num utensílio, de acordo com a função a que será destinado, podendo ser usado como uma vasilha, ou como urna funerária. A presença de depósitos, como cinzas ou resíduos orgânicos encontrados nos artefatos cerâmicos são indicadores do uso dos mesmos pelas sociedades antigas em sua vida cotidiana.

Além de proporcionar a forma desejada à pasta cerâmica, a temperatura também faz com que ocorram modificações em sua estrutura, tanto interna, como externa. Portanto, a faixa de temperatura em que a cerâmica foi queimada é um aspecto importante para a sua caracterização.

É importante destacar que, do ponto de vista macroscópico, por meio da observação da cor de uma cerâmica arqueológica, geralmente é possível estudar as condições em que esta foi queimada. Esse processo envolve o tipo de queima, o combustível utilizado e a quantidade de oxigênio presente durante a queima, ou seja, o tipo de atmosfera: oxidante, redutora ou neutra (CANOTILHO, 2003).

Podemos dizer que um tipo de queima bastante empregado no passado para a fabricação de cerâmicas foi a fogueira a céu aberto, que favorece o surgimento rápido de altas temperaturas com grande aproveitamento do combustível no início da combustão. Entretanto, na queima realizada em fornos, este tipo de queima rápida não acontece (NUNES, 2009).

De acordo com Machado (2005-2006) é apenas através do processo de queima que a argila passa a possuir as características conhecidas da cerâmica, como a dureza, a porosidade e a estabilidade. Dependendo da maneira como se faz a queima, ao ar livre ou em um forno, para Frédéric (1980) o resultado é diferente, tanto sob o ponto de vista da mudança da constituição da argila, como da cor definitiva das peças. Segundo este mesmo autor, na queima ao ar livre, a intensidade do fogo nunca ultrapassa os 500 a $600{ }^{\circ} \mathrm{C}$, e a cor da pasta, assim produzida, torna-se cinzenta ou negra. Havendo a presença de óxido de ferro a cor pode passar ao castanho avermelhado e se contiver muitas impurezas de origem orgânica pode então tornar-se cinzenta escura. Por outro lado em um forno é possível controlar a admissão de ar e se produzem efeitos 
diferentes, segundo a temperatura atingida (mais de $1000^{\circ} \mathrm{C}$ ) e a quantidade de oxigênio admitida

redução,

oxidação,

Tabela 2. Métodos de Cocção

\begin{tabular}{c|c}
\hline Oxidante & Redutora \\
\hline Livre circulação de $\mathrm{O}_{2}$ & Forno Fechado \\
Escape de $\mathrm{CO}_{2}$ & A Argila se impregna com \\
Coloração avermelhada & Anidrido carbônico $-\mathrm{CO}_{2}$ \\
Coloração escura
\end{tabular}

Fonte: Fréderic, 1980.

Frédéric (1980) destaca ainda alguns elementos relacionados ao processo de queima, passíveis de causarem alterações nos artefatos cerâmicos. São eles: a matéria orgânica; as pinturas ou engobes aplicados, de acordo com o conteúdo de óxidos, e se forem silicatados transformam-se em vidrado e verniz; a eliminação de carbono; o ponto de fusão da argila que varia com a sua composição; o tempo de queima; a posição da peça no forno; as labaredas, e os casos de redução parcial.

Podemos destacar a cor, a dureza, a resistência e a porosidade como propriedades ligadas diretamente ao tipo de queima. Segue abaixo uma síntese das trocas estruturais que podem acontecer em cerâmicas de baixa cocção (Tabela 3):

Tabela 3. Trocas estruturais em cerâmica de baixa cocção

\begin{tabular}{|c|c|}
\hline $\begin{array}{c}\text { Temperatura } \\
\text { em } \cong \mathrm{C}\end{array}$ & Processo \\
\hline $20-120$ & Secagem e perda de água de elaboração \\
\hline 200 & Desidratação do material orgânico (a cerâmica torna-se porosa) \\
\hline 350 & Mudança estrutural irreversível (ainda muito débil) \\
\hline 573 & $\begin{array}{l}\text { Inversão do quartzo - mudança de volume ao se transformar de } \\
\text { um estado a outro } \\
\text { Se as partículas de quartzo são grandes, pode promover } \\
\text { rachaduras } \\
\text { Não se deve abrir o forno acima desta temperatura; pois pode } \\
\text { ocorrer fragmentação }\end{array}$ \\
\hline 700 & Queima de carbono e do sulfato \\
\hline 850 & Processo de vitrificação \\
\hline 1100 & Máxima temperatura da cerâmica de baixa cocção \\
\hline
\end{tabular}


Fonte: Fréderic, 1980.

De acordo com Shepard (1961, p. 81) podemos dividir o processo de queima em três partes distintas:

\section{1) o período de desidratação:} quando a cerâmica é exposta a um baixo e gradual aquecimento para evitar a formação da pressão;

2) o período de oxidação: quando as moléculas de carbono são oxidadas juntamente com o ferro e outros componentes;

3) o período de vitrificação: durante esse período os componentes da cerâmica integram-se.

Durante todo esse processo, a obtenção de uma coloração uniforme depende da proteção da peça do contato direto com o fogo. Para tanto era comum entre os ceramistas pré-históricos a utilização de grandes fragmentos de cerâmica dispostos entre os vasos e o fogo e recobrindo-os.

Na opinião de Machado (2006), tal procedimento é dispensável se o objetivo do ceramista for obter uma superfície enegrecida. Ao falar das características técnicas da cerâmica é importante lembrar que a escolha dos materiais utilizados, tanto para a formação, quanto para a queima, é essencial, já que esses delimitarão as propriedades físicas das peças, garantindo determinado desempenho no exercício de uma função específica.

Para Machado (2005-2006), uma quantidade insuficiente de oxigênio produzirá condições redutoras. Se o ar for suficiente ao combustível, sem deixar excessos nem de um nem de outro, haverá um efeito neutro. $E$, se há excesso de oxigênio o resultado é oxidante.

Durante esse processo é possível que o ceramista controle a temperatura máxima e mínima atingida através do tipo do combustível utilizado e do tipo de forno no qual ela é feita. Outro fator de controle é a atmosfera que circunda as peças. O controle é feito através da quantidade de ar disponível para queimar a quantidade de combustível disposta no forno.

A coloração final da cerâmica deriva em grande parte do seu processo de queima. Quanto mais oxidante for a queima, mais claras as cores adquiridas pela cerâmica. O inverso também é verdadeiro, quanto mais redutor foi o processo, a cerâmica irá adquirir tonalidades mais escuras de cinza.

Machado (2005-2006) ainda destaca que na literatura a respeito de sociedades ceramistas tradicionais, pastas de coloração mais claras, vinculadas a ambientes de queima oxidantes, eram tidas como 
indicadores de processos de queima a céu aberto. No entanto, trabalhos de etnoarqueologia e experimentação demonstraram a existência de microambientes formados nos procedimentos de queima a céu aberto, criando tanto em ambientes oxidantes quanto redutores. Tal constatação pode ser comprovada nas peças que apresentam variações nas colorações da pasta, indicando tanto ambientes oxidantes quanto redutores ou queima incompleta.

A coloração da pasta é alterada por diversos fatores como composição da argila, qualidade e quantidade do antiplástico, posicionamento das peças na fogueira, entre outros.

Por sua vez, Rodrigues e Faccio (1998), na análise da cerâmica do sítio arqueológico Turvo II- SP revelaram que existe uma variação no tipo de queima das peças, onde as mesmas apresentaram-se com cor uniforme variando de cinza-claro ao pardo sem presença de núcleos; queima com presença do núcleo central escuro e uma camada interna e externa clara. E queima sem presença de núcleos, com cor uniforme variando do cinza escuro ao preto, porque o procedimento era feito em fogueira a céu aberto, não havendo o controle da temperatura.

Ainda para Rodrigues e Faccio (1998) as diferenças na cor indicam diferentes condições de duração da queima, ventilação e temperatura. A presença de núcleo com cor variando do laranja ao amarelo indica uma queima boa, com ventilação suficiente para ocasionar a oxidação da argila. A presença de tons que variam do cinza ao preto indica uma queima incompleta em baixa temperatura e tempo insuficiente para expelir toda a matéria carbonatada da argila.

Outras experiências realizadas por Belleti et al. (2004) revelam que as peças cerâmicas analisadas apresentaram diferentes níveis de oxidação quando da queima, causando assim variações quanto à distribuição da coloração ao longo da peça. $\mathrm{Na}$ totalidade das peças, suas superfícies internas não apresentaram sinais de redução, indicando que houve uma reoxidação completa. As superfícies externas das peças apresentaram graus variados de redução, predominando, porém, as superfícies reoxidadas sobre as reduzidas. Já no núcleo das peças ocorreu uma redução total em todas as peças, com exceção de uma, em que foi utilizado óxido de ferro como antiplástico e que em algumas partes apresentava reoxidação. Esta última, também devido ao antiplástico utilizado, apresentou uma coloração mais avermelhada do que as outras nas superfícies oxidadas. Naquelas em que foi utilizado carvão o resultado consistiu em uma coloração mais acinzentada nas superfícies oxidadas. Também se notou 
nestas que o carvão localizado nas superfícies foi consumido durante a queima, ao contrário do localizado no miolo, indicando que a temperatura durante a queima não atingiu igualmente a superfície e o centro da peça.

Estes autores destacaram que durante o início da queima, a céu aberto, com o abafamento da atmosfera, ocorre um processo de redução, que faz com que os pigmentos de ferro presentes na argila adquiram uma coloração escura, enegrecendo a peça. À medida que a temperatura se eleva e caso ocorra uma entrada de oxigênio na atmosfera de queima, os pigmentos de ferro começam a reoxidar e a peça aos poucos começa a clarear, ou seja, conforme o tempo de exposição ao fogo, a cerâmica pode obter diferentes características, entre elas a maior impermeabilidade ou maior resistência a choques.

Ramos et al. (2008) destacam em suas análises que em termos de cerâmica artesanal um dos óxidos que se deve observar, com a devida cautela, é o óxido de ferro, que é um dos responsáveis pela coloração avermelhada das peças quando queimadas, quanto mais ferro mais avermelhada será o produto final.

Assim, alguns trabalhos têm indicado que a forma mais adequada de se entender 0 processo de queima é a análise de alguns elementos componentes para se ter uma ideia da temperatura de queima, e, a partir daí inferir o procedimento utilizado.

\section{RESULTADOS}

Segundo Nunes (2009) os trabalhos sobre tecnologia das cerâmicas têm mostrado a relação entre a temperatura de queima e as transformações ocorridas na sua microestrutura (MIRTI et al. apud Nunes, 2009), bem como em sua composição mineralógica. A técnica analítica mais comumente utilizada para determinar a temperatura de queima da cerâmica relacionada com as mudanças mineralógicas em sua estrutura é a Difratometria de Raios-X (XRD - X Ray Diffraction).

Estes autores afirmam que as mudanças em sua microestrutura podem ser observadas diretamente pela Microscopia Eletrônica de Varredura (SEM - Scanning Electron Microscopy). A Espectroscopia de Ressonância Paramagnética (EPR - Electron Paramagnetic Resonance) também pode ser usada para a determinação da temperatura de queima das cerâmicas. Outras técnicas como a Espectroscopia Mössbauer e a Espectroscopia Raman também são empregadas em estudos de materiais arqueológicos.

Com a finalidade de identificar o tipo de atmosfera de queima e o tipo de argila utilizada pelos ceramista do sitio Evaristo I 
foram selecionadas oito amostras da cerâmica com diferentes cores no núcleo e na superfície interna e externa e uma amostra de sedimento da área do entorno das vasilhas (Tabela 4). Nesta primeira fase da pesquisa as amostras foram submetidas a técnica de Difratometria por Raios-X (RXD).

Tabela 4. Análise química e petrográfica do material cerâmico

\begin{tabular}{cccc}
\hline Identificação & Coloração & Composição & Observação \\
\hline EV-1025.3 & Cinza & Caulinita, Quartzo & \\
\hline EV-5385 & Cinza & Quartzo/llita & \\
EV-2147 & Cinza & Caulinita/Quartzo & \\
\hline EV-04238 & Cinza & Quartzo/llita & Mica no engobo \\
\hline EV-2151 & Laranja & Caulinita/Quartzo & \\
\hline EV-2313 & Laranja & Quartzo/ Ilita & \\
EV-V27A & Laranja & Quartzo/caulinita/llita & Local do sítio \\
\hline EV-V2C & Laranja & Quartzo/ Ilita & Quartzo/ Ilita \\
\hline Sedimento-4238 & & &
\end{tabular}

A técnica de Difratometria por Raios-X (RXD) possibilitou a identificação de dois tipos de argilominerais (Figuras 10 e 11) utilizadas pelos grupos pré-históricos ceramistas da Serra do Evaristo na produção da cerâmica (Figura 12).

Argila 1 : Ilita - $\left(\mathrm{K}, \mathrm{H}_{3} \mathrm{O}\right)(\mathrm{Al}, \mathrm{Fe}, \mathrm{Mg})_{2}(\mathrm{Si}$, Al) $)_{4} \mathrm{O}_{10}\left[(\mathrm{OH})_{2}, \mathrm{H}_{2} \mathrm{O}\right]$
Série dos argilominerais micáceos. Origem: Intemperismo ou alteração hidrotermal de muscovita-fengita. Também autigênicos alteração do K-feldspato ou recristalização de esmectita em sedimentos marinhos (Figura 10). 


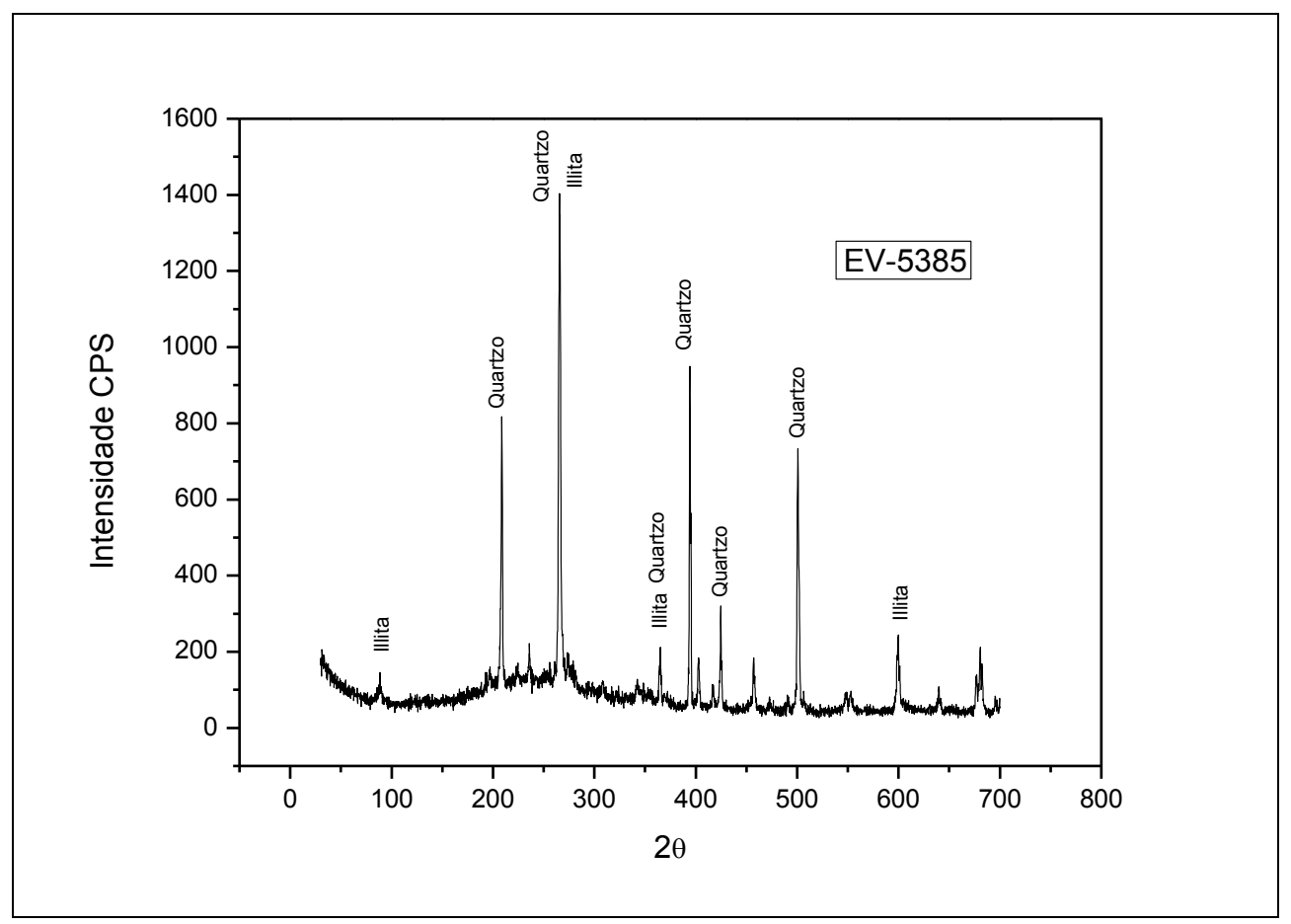

Figura 10. Difratograma 01 - Composição da cerâmica, Ilita e Quartzo

Argila 2: Caulinita - Silicato básico de alumínio - $\mathrm{Al}_{2} \mathrm{Si}_{2} \mathrm{O}_{5}(\mathrm{OH})_{4}$.Grupo da Caulinita. Origem: Principal constituinte do caulim, mineral secundário derivado de intemperismo de minerais alumino-silicatos (Figura 11).

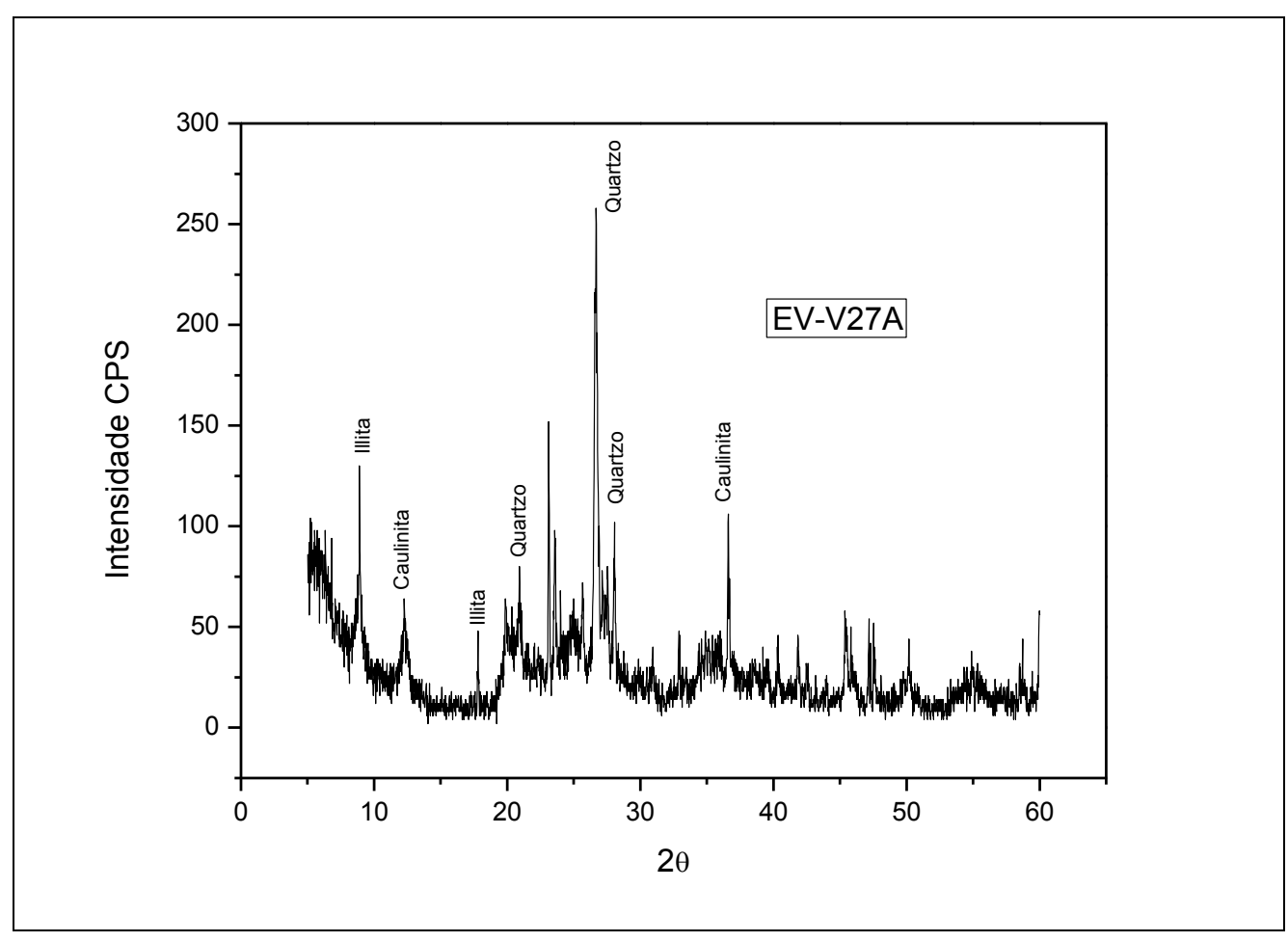

Figura 11. Difratograma 02 - Composição da cerâmica, llita, caulinita e Quartzo 


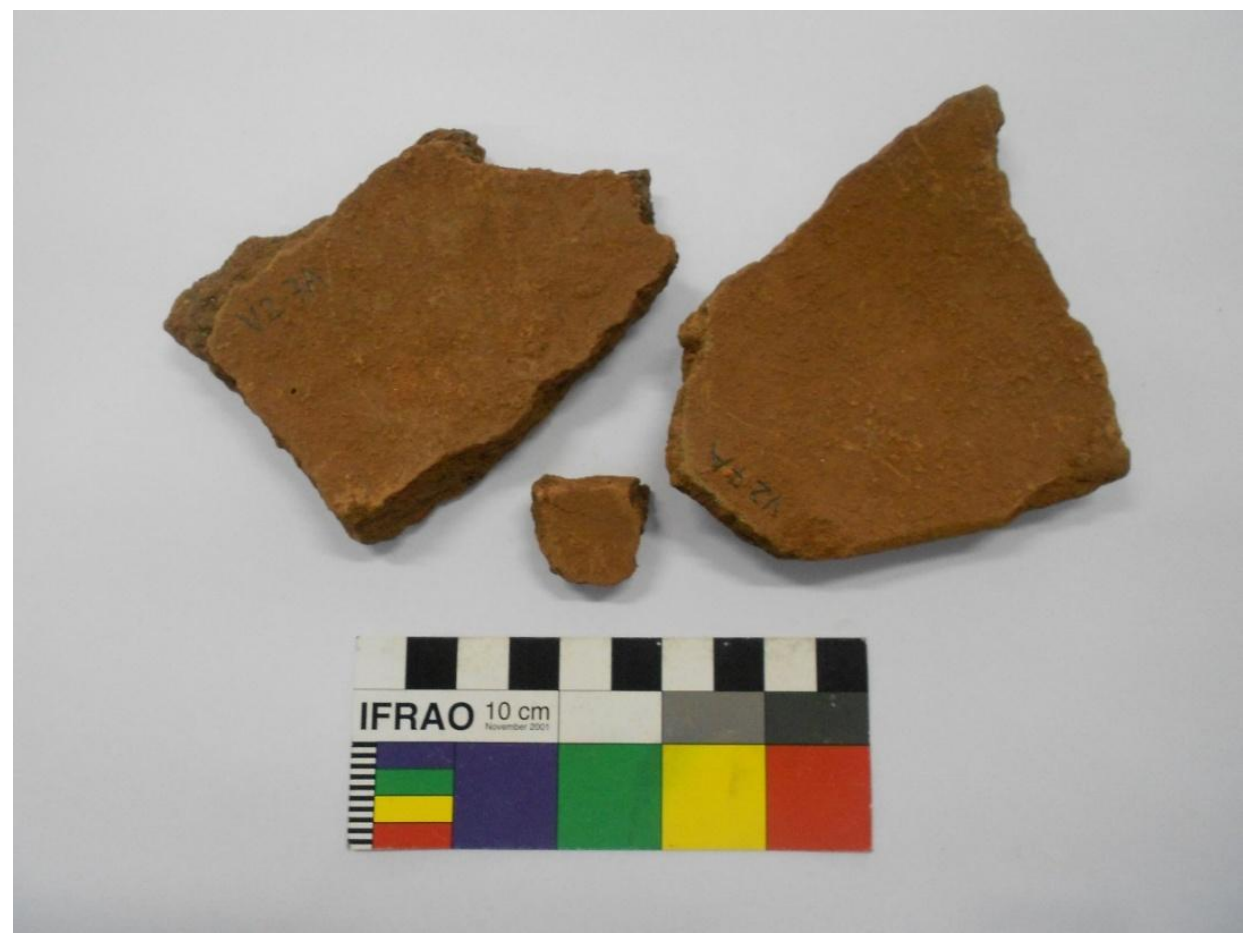

Figura 12. Cerâmica EV-V27A - combinação de dois argilominerais

Fonte: Neuvania Guethi

\section{CONCLUSÕES}

No estudo da tecnologia cerâmica dos Caingang paulistas, Miller (1978, p.27) afirma que a queima redutora seria uma técnica não desenvolvida "entre os povos do leste da América do Sul" e que a cor preta da cerâmica Caingang advém da técnica do esfumaramento ao inserir a peça em brasa num ambiente de material orgânico, assim produzindo uma atmosfera de redução, depois de terminado o processo de oxidação.

Conforme Wiley (1986) a queima da cerâmica poderia ser a céu aberto ou em fornos. Quando feita em fogueiras produzia vasos sujos de fuligem, marrons, pretos ou castanho-couro. O controle da oxidação tendia a ser desigual e acidental. Em sua maior parte, a queima a céu aberto foi e é característica das terras baixas orientais e do sul da América do Sul. A queima em forno é típica das regiões andinas. Fornos com correntes de ar forte, produzida por aberturas tanto no alto quanto no fundo, davam uma coloração vermelha oxidada às peças após a queima. Fornos com pouca entrada de ar, produzindo uma combustão lenta, conferiam às mesmas um tom acinzentado ou preto fosco. A cerâmica preta era comum no Peru, particularmente na costa norte, no final do período Chimu. As peças pretas, ou bucchuero, são também encontradas na Nicarágua, Panamá, norte da Colômbia, Equador, sul do Peru e sul dos Andes.

A partir dessa pesquisa pode-se inferir que na cerâmica do sítio Evaristo I: 
1- Os ceramistas da Serra do Evaristo utilizavam argilas de dois depósitos distintos;

2- De acordo com o tipo de vasilha utilizava-se um único tipo de argila;

3- De acordo com o tipo de vasilha poderia misturar os dois tipos de argilas como mostra o Difratograma 02;

4- Em relação a diferenciação da cor da cerâmica a variação observada indica diferentes métodos de queima. Ou seja, no mesmo tipo de argila foi verificada a variação de cor da cerâmica, indicando a queima em atmosfera redutora e oxidante.

O contraste nas pastas nos dois tipos de argilas mostra a diferença no processo da queima das argilas, e indicam que as diferença de cores nos tipos cerâmicos são devidos primeiramente às diferenças no método de queima. Desta forma a diferenciação da queima identificada na cerâmica da Serra do Evaristo I demonstra como os ceramistas selecionavam os materiais e as técnicas de confecção das peças utilizando diferentes técnicas de queima. Essa pesquisa levanta novos questionamentos sobre $\mathrm{o}$ processo de produção da cerâmica nesta área. As amostras analisadas indicam uma nova técnica de queima da cerâmica por grupos pré-históricos podendo servir como um diferenciador de tecnologias distintas.

\section{AGRADECIMENTOS}

À Superintendência estadual do Iphan no Ceará (IPHAN-CE). À comunidade da Serra do Evaristo e à empresa Arqueosocio.

\section{REFERÊNCIAS}

AB'SÁBER, A. N. Redutos Florestais, Refúgios de Fauna e Refúgios de Homens. Revista de Arqueologia, São Paulo, v. 8, n. 2, p. 1-36, 1994-1995.

ARNALDO, E. Arquivo pessoal. Presidente Prudente, 2015.

BELLETI, J. S. et al. Arqueologia experimental: interpretação e produção de artefatos cerâmicos. Laboratório de Ensino e Pesquisa em Antropologia e Arqueologia. Pelotas: Instituto de Ciências Humanas/ UFPe, 2004.

CANOTILHO, M. H. P. C. Processos de cozedura em cerâmica. Bragança: Instituto Politécnico de Bragança, 2003. (Séries Estudos, 60).

CAVALCANTE, A. M. B. A Serra de Baturité. Fortaleza: Edições Livro Técnico, 2005.

CEARÁ. Superintendência Estadual do Meio Ambiente. Zoneamento ambiental da APA da Serra de Baturité: diagnóstico e Diretrizes. Fortaleza: Semace, 1992.

FRÉDÉRIC, L. Manual prático de arqueologia. Coimbra: Livraria Almediana, 1980.

GHETTI, N. C. Estudios del proceso de quema de cerámica Prehistórica de la zona arqueologica Serra do Evaristo, Baturité - 
CE/ Brasil. II Congreso Internacional sobre Estudios Cerámicos, Granada, Espanha2013.

IBAMA. Ministéro do Meio Ambiente. Planejamento biorregional do Maciço de Baturité. Fortaleza: Banco do Nordeste, 2002. IPECE. Perfil básico municipal (Baturité). Fortaleza: Ipece, 2014.

MANTOVANI, W. Conservação de biodiversidade: importância das serras úmidas no nordeste semi-árido brasileiro. In: OLIVEIRA, T. S.; ARAÚJO, F.S. (Org.). Diversidade e conservação da biota na serra de Baturité, Ceará. Fortaleza: Edições UFC/ COELCE, 2007. v.1, p. 1-14.

MACHADO, J. S. O potencial interpretativo das análises tecnológicas: um exemplo amazônico. Rev. do Museu de Arqueologia e Etnologia, São Paulo, n.15-16, p. 87-111, 2005-2006.

MILLER, E. T. Tecnologia cerâmica dos Caingang paulistas. Arquivo do Museu Paranaense. Curitiba, 1978. (Nova Série Etnologia).

NIMER, E. Climatologia do Brasil. Rio de Janeiro: Instituto Brasileiro de Geografia e Estatística, 1989.

NUNES, K. P. Estudos Arqueométricos do sítio Arqueológico Hatahara. 71p. 2009. Dissertação (Programa de Pós-Graduação do Instituto e Pesquisas Energéticas e Nucleares) - Universidade de São Paulo, São Paulo.

NUNES, F. P.; PORTELA, S. V. S. Plano de manejo da Reserva Particular do Patrimônio Natural - RPPN Sítio Palmeiras. [S.I.]: [s.n.], 2011.

OLIVEIRA, T. S.; ARAÚJO, F. S. Diversidade e conservação da biota na serra de Baturité, Ceará. Fortaleza: Edições UFC/ COELCE, 2007. v. 1 , p. 70-133.
PEDROZA, I. Arquivo pessoal. Presidente Prudente, 2015.

RAMOS, I. S. et al. A indústria cerâmica vermelha de Campos dos Goitacazes e a inclusão social das artesãs da baixada campista através do projeto Caminhos de Barro. Revista Cerâmica, n.54, p. 280-286, 2008.

RODRIGUES, B. G.; FACCIO, N. B. Análise da cerâmica do sítio arqueológico Turvo II- SP. São Paulo: Programa de Formação Complementar/UNESP, 1998.

RYE, O. S. Pottery technology principles in reconstruction. Washington, D. C.: [s.n.], 1981. (Manuals On Archaeology, v.4).

SHEPARD, A. O. Ceramics for the Archaeologist. 4. ed. Washington D. C.: Carnegie Institution of Washington, 1961.

SOUZA, M. J. N. Contexto Ambiental do enclave úmido da Serra de Baturité-CE. In: BASTOS, F. H. (Org.). Serra de Baturité: uma visão integrada das questões ambientais. Fortaleza: Expressão Gráfica e Editora, 2011. p 19-33.

VELOSO, H. P.; RANGEL FILHO, A. L. R.; LIMA, J. C. A. Classificação da vegetação brasileira, adaptada a um sistema universal. Rio de Janeiro: IBGE, Departamento de Recursos Naturais e Estudos Ambientais, 1991.

WILEY, G. R. Ceramic. In: RIBEIRO, D. (Org.). Suma etnológica brasileira. Petrópolis: Vozes, 1986. v. 2, p. 231- 281.

Recebido para publicação em 30/08/2014

Revisado em 04/09/2015

Aceito em 08/09/2015 